\title{
Contraceptive Knowledge, Attitude and PracticeAmong Eligible Couples of Rural Haryana
}

\author{
N Saluja, S Sharma, S Choudhary, D Gaur, S Pandey
}

\begin{abstract}
Citation
N Saluja, S Sharma, S Choudhary, D Gaur, S Pandey. Contraceptive Knowledge, Attitude and PracticeAmong Eligible Couples of Rural Haryana. The Internet Journal of Health. 2011 Volume 12 Number 1.
\end{abstract}

DOI: $\underline{10.5580 / 156 \mathrm{e}}$

\begin{abstract}
Objective: To assess the knowledge, attitude regarding family planning and the practice of contraceptives among eligible couples of rural Haryana. Study Design: Cross-sectional. Setting: Agroha village. Participants: 250 eligible couples. Methodology: The primary tool in this study was predesigned and pretested questionnaire for recording of individual informations. Result:The knowledge about one or more methods of contraception, particularly modern contraceptive methods was $95.0 \%$, being $95.6 \%$ among males and $94.4 \%$ among females. The knowledge about traditional methods of contraception was $72.0 \%$ in males and $46.4 \%$ in females. The most common source of knowledge for all couples in general was the "Exposure to family planning messages" (72.0\%) followed by discussion with doctors and other health care workers (42.6\%). Sex-wise, the most common source of knowledge for males as well as females was "Exposure to family planning messages" (75.2\% and $68.8 \%$ respectively). Of 250 interviewed couples, $148(59.2 \%)$ were practicing different contraceptive methods. Completion of family was found to be the most common reason for using contraception (81.1\%). Fertility related reasons (45.1\%) followed by husband's opposition (28.4\%) were the common reasons for not using contraception. Positive attitude for contraception was shown by 198 (79.2\%) females and $158(63.2 \%)$ males. Conclusion: The study reveals good knowledge and favourable attitude of rural couples towards contraception. The study also highlights that awareness does not always lead to the use of contraceptives. A lot of educational and motivational activities and improvement in family planning services are needed to promote the use of contraceptives and reduce the high fertility rate.
\end{abstract}

\section{INTRODUCTION}

India was the first country in the world to formulate the national family planning program in the year 1952 with the objective of " reducing the birth rate of the extent necessary to stabilize the population at a level consistent with requirement of National economy" . One of the main objective of the programme is to spread the knowledge of family planning methods and develop among the people an attitude favourable for adoption of contraceptive methods. The progress achieved in this sphere is normally assessed from the result of Knowledge, Attitude and Practice (KAP) Survey $^{2}$. Despite the fact that contraceptive usage has increased over a period of time, there exists a KAP-gap i.e. a gap between the knowledge, attitude and practices regarding contraception ${ }^{3}, 4$. In a developing country like India, over population is a major concern. Despite progress resulting from making contraception widely available, there is poor acceptance of contraceptive methods either due to ignorance or fear of complications using them ${ }^{5,6,7,8}$. Inadequate knowledge about contraceptive methods and incomplete or erroneous information about their use or where to procure them are the main reasons for not accepting family planning. Keeping all the se facts in view this study was carried out to assess the knowledge, attitude and practice of contraceptive methods among eligible couples in rural area of Haryana.

\section{MATERIALS AND METHODS}

The present cross-secctional, observational study was carried out from Nov 2008 to Feb 2009 among 260 randomly selected eligible couples out of a total of 1340 eligible couples residing in Agroha village of Hisar distt., which is the Rural Field practice area of the Department of Community Medicine, Maharaja Agrasen Medical Institute of Education and Research, Agroha, Hisar (Haryana).Two hundred and fifty (250) willing couples were interviewed, based upon a pre-designed and pre-tested questionnaire. The 
questionnaire elicited information regarding their age, educational status, income, knowledge and source of contraceptive methods, practicing of either male or female family planning methods. Women and men were asked about their knowledge regarding different methods of contraception. Information on knowledge of contraception was collected in two ways. First, respondents were asked to spontaneously mention all the methods of contraception that they had heard of. For methods not mentioned spontaneously, the interviewer described the method and probed for whether the respondent recognized it. Information was collected on the knowledge of female and male sterilization, the pill, the IUD, injectables, male condoms, female condoms, emergency contraception, and any traditional method. The social class of the sample group was determined by modified BG Prasad's classification ${ }^{9}$ (2008). The data was collected by the Interns who were extensively trained for data collection and the survey was conducted under the guidance of the authors. Descriptive analysis was conducted to describe the results in percentages.

\section{RESULTS}

Table-1 shows the socio-demographic characterstics of the study population.

\section{Figure 1}

Table 1: Socio-demographic characterstics of the study population

\begin{tabular}{|c|c|c|c|}
\hline $\begin{array}{l}\text { Socio-demographic } \\
\text { characterstics }\end{array}$ & $\begin{array}{l}\text { Women } \\
(\mathrm{n}=250)\end{array}$ & $\begin{array}{c}\text { Men } \\
(n=250)\end{array}$ & $\begin{array}{c}\text { Total } \\
(\mathrm{n}=500)\end{array}$ \\
\hline \multicolumn{4}{|l|}{ Age Group (years) } \\
\hline $15-24$ yrs. & $60(24.0)$ & $48(19.2)$ & $108(21.6)$ \\
\hline $25-34$ yrs. & $110(44.0)$ & $117(46.8)$ & $227(45.4)$ \\
\hline $35-44$ yrs. & $80(32.0)$ & $85(34.0)$ & $165(33.0)$ \\
\hline \multicolumn{4}{|l|}{ Literacy status } \\
\hline Illiterate & $65(26.0)$ & $47(18.8)$ & $112(22.4)$ \\
\hline Primary School Complete & $60(24.0)$ & $65(26)$ & $125(25.0)$ \\
\hline Middle School Complete & $85(34.0)$ & $66(26.4)$ & $151(30.2)$ \\
\hline High School Complete \& above & $40(16.0)$ & $72(28.8)$ & $112(22.4)$ \\
\hline \multicolumn{4}{|l|}{ Caste } \\
\hline SC & $50(20.0)$ & $50(20.0)$ & $100(20.0)$ \\
\hline$\overline{O B C}$ & $86(34.4)$ & $86(34.4)$ & $172(34.4)$ \\
\hline Others & $114(45.6)$ & $114(45.6)$ & $228(45.6)$ \\
\hline \multicolumn{4}{|l|}{ Type of Family } \\
\hline Nuclear & $100(40.0)$ & $100(40.0)$ & $200(40.0)$ \\
\hline Joint & $150(60.0)$ & $150(60.0)$ & $300(60.0)$ \\
\hline \multicolumn{4}{|c|}{ Social Class (Modified B.G Prasad's classification) } \\
\hline I & $42(16.8)$ & $42(16.8)$ & $84(16.8)$ \\
\hline II & $48(19.2)$ & $48(19.2)$ & $96(19.2)$ \\
\hline IIII' $^{12}$ & $38(15.2)$ & $38(15.2)$ & $76(15.2)$ \\
\hline $\mathrm{IV}^{2}$ & $42(16.8)$ & $42(16.8)$ & $84(16.8)$ \\
\hline V & $80(32.0)$ & $80(32.0)$ & $160(32.0)$ \\
\hline
\end{tabular}

Note: Figures in parenthesis indicate percentages.

The knowledge about one or more methods of contraception, particularly modern contraceptive methods was $95.0 \%$, being $95.6 \%$ among males and $94.4 \%$ among females. The knowledge about traditional methods of contraception was $72.0 \%$ in males and $46.4 \%$ in females (Table 2). 


\section{Figure 2}

Table 2: Knowledge of Contraceptive Methods (Multiple Response)

\begin{tabular}{|c|c|c|c|c|c|c|}
\hline \multirow{2}{*}{ Contraceptive method } & \multicolumn{2}{|c|}{$\begin{array}{c}\text { Women } \\
(\mathbf{n}=\mathbf{2 5 0})\end{array}$} & \multicolumn{2}{c|}{$\begin{array}{c}\text { Motal } \\
(\mathbf{n}=\mathbf{2 5 0})\end{array}$} & \multicolumn{2}{c|}{$(\mathbf{n = 5 0 0 )}$} \\
\cline { 2 - 7 } & No. & $\%$ & No. & $\%$ & No. & $\%$ \\
\hline Any Method & 240 & 96.0 & 246 & 98.4 & 486 & 97.2 \\
\hline Any Modem Method & 236 & 94.4 & 239 & 95.6 & 475 & 95.0 \\
\hline Female sterilisation & 230 & 92.0 & 236 & 94.4 & 466 & 93.2 \\
\hline Male sterilisation & 199 & 79.6 & 232 & 92.8 & 431 & 86.2 \\
\hline Oral Pills & 226 & 90.4 & 208 & 83.2 & 434 & 86.8 \\
\hline IUCD & 206 & 82.4 & 182 & 72.8 & 388 & 77.6 \\
\hline Injectables & 98 & 39.2 & 96 & 38.4 & 194 & 38.8 \\
\hline Condom & 210 & 84.0 & 246 & 98.4 & 456 & 91.2 \\
\hline Female Condom & 7 & 2.8 & 22 & 8.8 & 29 & 5.8 \\
\hline Emergency Contraception & 27 & 10.8 & 55 & 22.0 & 82 & 16.4 \\
\hline Any Traditional Method & 124 & 49.6 & 180 & 72.0 & 304 & 60.8 \\
\hline
\end{tabular}

Most common source of knowledge for all couples in general was the "Exposure to family planning messages" (72.0\%) followed by discussion with doctors and other health care workers $(42.6 \%)$. Sex-wise, the most common source of knowledge for males as well as females was "Exposure to family planning messages" $(75.2 \%$ and $68.8 \%$ respectively) (Table 3).

\section{Figure 3}

Table 3: Source of Knowledge of Family Planning Methods (Multiple Response)

\begin{tabular}{|l|c|c|c|c|c|c|}
\hline \multirow{2}{*}{ Source of Knowledge } & \multicolumn{2}{|c|}{$\begin{array}{c}\text { Women } \\
\text { (n=250) }\end{array}$} & \multicolumn{2}{c|}{$\begin{array}{c}\text { Men } \\
\text { (n=250) }\end{array}$} & \multicolumn{2}{c|}{$\begin{array}{c}\text { Total } \\
(\mathbf{n}=500)\end{array}$} \\
\cline { 2 - 7 } & No. & $\%$ & No. & $\%$ & No. & $\%$ \\
\hline $\begin{array}{l}\text { Exposure to family } \\
\text { planning message (Mass } \\
\text { Media) }\end{array}$ & 172 & 68.8 & 188 & 75.2 & 360 & 72.0 \\
\hline $\begin{array}{l}\text { Discussion with friends/ } \\
\text { relatives / spouse }\end{array}$ & 62 & 24.8 & 46 & 18.4 & 108 & 21.6 \\
\hline $\begin{array}{l}\text { Discussion with doctor/ } \\
\text { other health care worker }\end{array}$ & 115 & 46.0 & 98 & 39.2 & 213 & 42.6 \\
\hline
\end{tabular}

Of 250 interviewed couples, 148 (59.2\%) were practicing different contraceptive methods. Completion of family was found to be the most common reason for using contraception $(81.1 \%)$ and fertility related reasons $(45.1 \%)$ followed by husband's opposition (28.4\%) were the common reasons for not using contraception (Table 4).
Figure 4

Table 4: Practices of Contraception

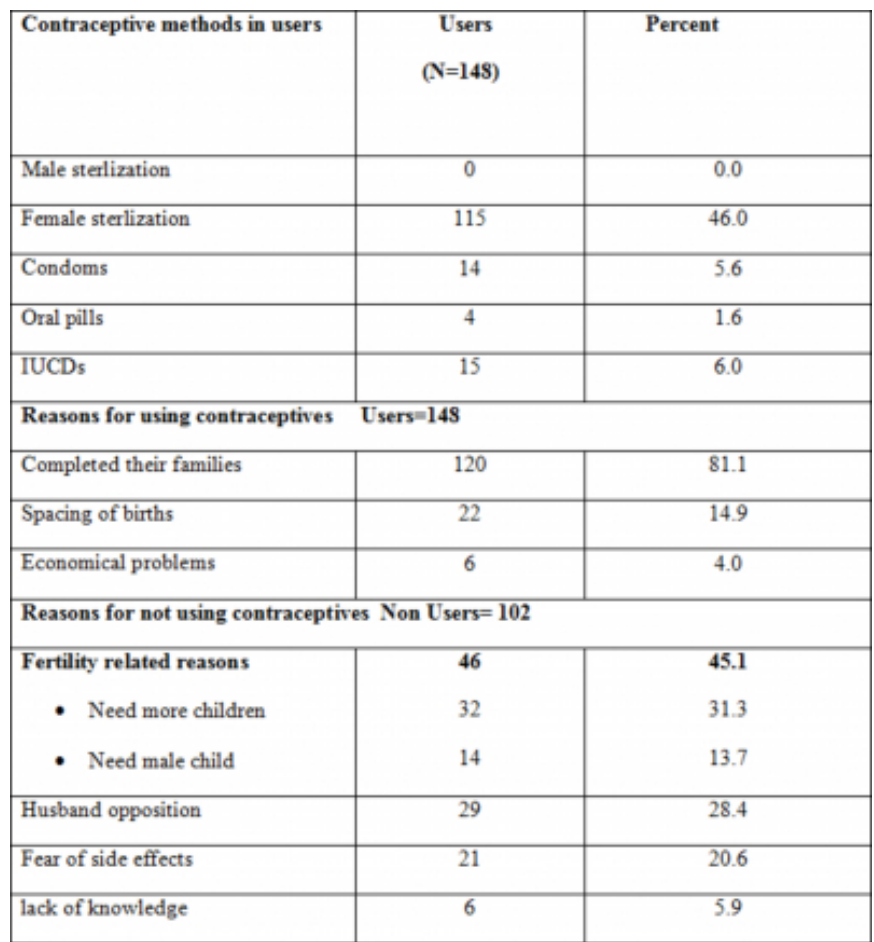

Table- 5 shows the attitude of males and females towards contraception. Positive attitude for contraception was shown by $198(79.2 \%)$ females and $158(63.2 \%)$ males.

\section{Figure 5}

Table 5: Attitude towards contraception

\begin{tabular}{|c|c|c|c|}
\hline $\begin{array}{c}\text { Attitude for } \\
\text { contraception }\end{array}$ & $\begin{array}{c}\text { Total }=\mathbf{2 5 0} \\
\text { n (\%) }\end{array}$ & $\begin{array}{c}\text { Users }=148 \\
\text { n (\%) }\end{array}$ & $\begin{array}{c}\text { Non users }=102 \\
\text { n (\%) }\end{array}$ \\
\hline \multicolumn{4}{|l|}{ Females } \\
\hline Approval & $198(79.2)$ & $130(87.8)$ & $68(66.7)$ \\
\hline Disapproval & $52(20.8)$ & $18(12.2)$ & $34(33.3)$ \\
\hline \multicolumn{4}{|l|}{ Males } \\
\hline Approval & $158(63.2)$ & $132(89.2)$ & $26(25.5)$ \\
\hline Disapproval & $92(36.8)$ & $16(10.8)$ & $76(74.5)$ \\
\hline
\end{tabular}

\section{DISCUSSION}

Family planning is defined by WHO as, "a way of thinking and living that is adopted voluntarily, upon the basis of knowledge, attitudes and responsible decisions by individuals and couples, in order to promote the health and welfare of family groups and thus contribute effectively to the social development of a country".

The widespread adoption of family planning, in a society, is an integral component of modern development and is essential for the integration of women into social and 
economic life. The present study aimed to assess the knowledge, attitude and practice of family planning methods to enhance the contraceptive practice in the rural community in future. Results showed that the overall knowledge about any method of contraception was $97.2 \%$ (98.4\% in men and $96.0 \%$ in women). The findings are similar to prevalence of knowledge ( $98.2 \%$ in men \& $97.7 \%$ in women) reported by NFHS-III (2005-06) ${ }^{10}$ and slightly lower than the findings of Takkar et $\mathrm{al}^{11}(100 \%)$, but higher than $78.8 \%, 75.0 \%, 73.5 \%$ \& $95.0 \%$ as reported by Jain et $\mathrm{al}^{12}$, Kumar et $\mathrm{al}^{13}$, Chandhick et $\mathrm{al}^{14}$ and Patro et $\mathrm{al}^{15}$ respectively. The knowledge was higher for female sterlization (93.2\%) and low for spacing methods $(86.8 \%, 77.6 \%$, \& 91.2\% for Oral Pills, IUCD, \& Condom respectively) and male sterlization (86.2\%). Jain et $\mathrm{al}^{12}$ reported highest knowledge for condoms (55.6\%) followed by female sterilisation $(55.4 \%)$ in rural area of Meerut which may be due to differences in educational and socio-economic background.

Exposure to family planning messages through media play an important role in increasing the use of family planning methods especially in those areas where literacy level is low. Fikree et $\mathrm{al}^{16}$ stated that women were more likely to use contraceptives when messages of family planning were delivered through media. In the present study, exposure to family planning messages $(72.0 \%)$ followed by health personnel $(42.6 \%)$ and social circle (discussion with friends/relatives/spouse) (14.8\%) have contributed to impart knowledge for contraception. Similarly, study from rural Nepal also reported an exposure to electronic media messages as the main factor for use of family planning methods among women ${ }^{17}$. An Ethiopian study showed that $80.3 \%$ of health personnel contributed in providing information regarding contraception, which is opposite to the results ${ }^{18}$ In a study by Srivastava et al $^{19}$, social circle $(67.3 \%)$ and exposure to family planning messages $(46.3 \%)$ were the main sources of knowledge about contraception.

Only $59.2 \%$ of the interviewed couples were practicing family planning methods. Our findings of 59.2\% contraceptive usage is quite similar to a study by Bhasin et $\mathrm{al}^{20}$.In contrast the prevalence of contraceptive use was found to be very low (34.9\%) in a study by Gaur et $\mathrm{al}^{21}$ in rural muslim area of Haryana. Regarding the usage of family planning methods, an important dimension is the type of contraception used. Female sterlization was the most common chosen method used by $46.0 \%$ of couples which is similar to the findings of Bhasin et $\mathrm{al}^{20}$, Kansal $\mathrm{et}^{22}$ al and Girdhar et $\mathrm{al}^{23}$. Couples not practicing contraception were
$40.8 \%$ and was lower as compared to other studies which showed $55 \%$ and $44.6 \%{ }^{19,24}$. Fertility related reason i.e., need more children (31.3\%), partner's opposition (28.4\%) and fear of side effects $(20.6 \%)$ were the reasons found for nonuse of contraception. Reasons for non-use of contraceptives have varied in magnitude in different studies - Fertility related reasons were found as main reasons by Das et $\mathrm{al}(38.9 \%)^{25}$, Vaidya et al $(17.8 \%)^{26}$, Chandhick et $\mathrm{al}^{14}$ $(34.6 \%)$, Khokhar et al $(30.7 \%)^{27}$ and Bhasin et al $(36.4 \%)^{20}$ respectively. Other studies mention "hesitation" (Jain et al) ${ }^{12}$, "scared of side-effects" (Khokhar et al) ${ }^{28}$ and "opposition from family" (Anju et $\mathrm{al}^{29}$ and Dhillon et $\mathrm{al}^{30}$ ) as biggest reasons for non-use of contraception in their studies.

In our study more females $(79.2 \%)$ showed positive attitude for contraception as compared to $(20.8 \%)$ females who showed negative attitude, similar to the findings of $\mathrm{J} \mathrm{Mao}^{2}$ where $60 \%$ females approved and $28 \%$ disapproved the use of contraceptive methods. Approval of family planning was shown by $63.2 \%$ of males, in contrast to other studies, where $78 \%$ and $74 \%$ of husbands approved the use of contraceptive methods at the time of survey. ${ }^{31,32}$ In the present study, $36.8 \%$ of males disapproved family planning, which is lower than the findings (59\%) of Mustafa et $\mathrm{al}^{33}$. However, husband support for family planning was significantly higher in a Jordanian study ${ }^{34}$. Attitude of husband was found to be an important predictor for contraception use. In rural areas, husband being the dominant member plays the pivotal role in approving the family size and contraceptive practices. Education is, therefore, considered to improve the ability of women to resist subjugation and to acquire greater power in decision-making. Family Planning services thus need to provide a range of quality methods for family planning that can allow women to either limit or space births, and to focus services to the individual needs of women with differing sociodemographic characteristics.

\section{CONCLUSION}

The study reveals good knowledge and favourable attitude of rural couples towards contraception. Contraceptive knowledge and practice was influenced by exposure to family planning messages and partner opposition. Women education and counseling of couples can play an important role to adopt family planning methods. The couples should be given information about contraceptives at every visit to the health services to motivate them. The most important factor is regular availability of contraceptives and adequate health care services at the peripheral level. Electronic media, health personnel and government's organizations can play a 
positive role to provide knowledge and overcome the knowledge/practice gap.

\section{References}

1. National Population Policy-2000, Government of India. 2. Mao J. Knowledge, Attitude ands Practice of Family Planning (A Study of Churachandpur District, Manipur). Indira R, Behera DK, editors. Gender and Society. Vol.II. New Delhi: Vedams e Books (P) Ltd. 1999.

3. Charles W, Ann P. Alternative measure for Unmet Need for Family Planning in Developing Countries. Int Fam Plan Perspect. 2000;7(4):126-135

4. Ashoke S, John S and Jayanti M.T.The KAP-Gap in Nepal: Reasons for Non-use of Contraception Among Couples with an Unmet Need for Family Planning. AsiaPacific Population Journal, 2000;6(1):25-38.

5. Lodewijck E. Attitudes towards contraception and some reasons for discontinuation. Contracept Fertil Sex, 1987;15(1(11):1025-30.

6. Gilliam ML, Warden M, Goldstein C, Tapia B. Concerns about contraceptive side effects among young Latinas: a focus group approach. Contraception, 2000;70(4):299-305.

7. Castle S. Factors influencing young Malians reluctance to use hormonal contraceptives. Stud Fam Plann,

2003;34(3):186-99

8. Orji EO, Onwudiegwu U. Prevalence and determinants of contraceptive practice in a defined Nigerian population. $\mathrm{J}$ Obstet Gynaecol, 2002;22(5):540-3.

9. Suryakantha AH (2009). Community Medicine with Recent Advances. 1st edition: 659-60.

10. National Family Health Survey (NFHS-3), 2005-06, India. International Institute for Population Sciences, Mumbai.

11. Takkar N, Goel P, Dua D. Contraceptive practices and awareness of emergency contraception in educated working women. Indian J Med Sci. 2005; 59:143-149.

12. Jain S, Singh JV, Bhatnagar M, Garg SK, Chopra H, Bajpai SK. Attitude of rural women towards contraceptive and its use. Indian J Matern Child Health. 1999; JanMar10(1):18-9

13. Kumar R, Singh MM, Kaur M. Dynamics of contraceptive use in rural community of Haryana. Indian J Med Sci. 1999; 53(5):201-11.

14. Chandhick N, Dhillon BS, Kambo I, Saxena NC. Contraceptive knowledge, practices and utilisation of services in rural areas of India (an ICMR task force study). Indian J Med Sci. 2003;57(7):303-10

15. Patro BK, Kant S, Baridalyne N, Goswami AK. Contraceptive practices among married women in a resettlement colony of Delhi. Health and Population Perspectives and Issues. 2005:28(1);9-16

16. Fikree FF, Khan A, Kadir MM, Sajan F, Rahbar MH. What influences contraceptive use among young women in urban squatter settlements of Karachi, Pakistan? Int Fam Plann Perspect. 2001; 27:130-6.

17. Boulay M, Storey JD, Sood S. Indirect exposure to a family planning mass media campaign in Nepal. J Health Commun. 2002;7:379-99
18. Senbeto E. A study on knowledge, attitude, practice and quality of care in family planning at Dessie Zuria District. J Ethiop Med Pract. 2001; 3:70-6.

19. Srivastava R, Srivastava DK, Jina R, Srivastava K, Sharma N, Sana S. Contraceptive knowledge, attitude and practice (KAP Survey). J Obstet Gynecol. 2005; 55: 546-50. 20. Bhasin SK, Pant M, Metha M, Kumar S. Prevalence of Usage of Different Contraceptive Methods in East Delhi- A Cross Sectional Study. Indian J Of Community

Medicine,2005; Vol 30 (2) :53-55.

21. Gaur D.R., Goel M.K., Goel M. Contraceptive practices and related factors among females in predominantly rural Muslim area of North India. The Internet J of World health and Societal Politics, 2008; 5(1).

22. A Kansal, R Chandra, S D Kandpal, K.S

Negi.Epidemiological Correlates of contraceptive

Prevalence in Rural Population of Dehradun District". Indian J Of Community Medicine ,2005; Vol 30 (2) : 60-62

23. S. Girdhar, A. Chaudhary, P. Gill, R. Soni \& R. K.

Sachar : Contraceptive Practices And Related Factors

Among Married Women In A Rural Area Of Ludhiana. The Internet Journal of Health. 2010; Vol 12(1).

24. Prachi R, Das GS, Ankur B, Shipra J, Binita K. A study of knowledge, attitude and practice of family planning among the women of reproductive age group in Sikkim. J Obstet Gynecol. 2008; 58: 63-7.

25. Das R, Amir A, Nath P. Utilisation and coverage of services by women of Jawan Block in Aligarh. Indian $\mathrm{J}$ Comm Med. 2001; Apr-Jun:26(2).

26. Vaidya VG, Sahasrabudhe BG, Jogi JA, Mitkar RP. Profile of sterilized women in urban slums and evaluation of motivational strategies. Indian J Public Health. 2003; JanMar47(1):31-3.

27. Khokhar A, Mehra M. Contraceptive use in women from resettlement area in Delhi. Indian J Comm Med. 2005; Mar:30(1).

28. Khokhar A, Gulati N. A study of never users of contraception from an urban slum of Delhi. Indian J Comm Med. 2000; Jan-Mar:25(1).

29. Anju P, Suneeta G, Mehra M. Assessment of Unmet Need for Contraception in an urban slum of Delhi. Indian J Comm Med. 2004; Jul-Sept:29(3).

30. Dhillon BS, Chandhiok N, Kambo I, Saxena NC. Induced abortion and concurrent adoption of contraception in rural areas of India (an ICMR task force study). Indian J Med Sci. 2004;58(11):478-84.

31. Ali S, White FMM. Family planning practices among currently married women in Khairpur District, Sindh, Pakistan.J Coll Physicians Surg Pak. 2005; 15: 422-5. 32. Khawaja NP, Tayyab R, Malik N. Awareness and practices of contraception among Pakistani women attending a tertiary care hospital. J Obstet Gynaecol.2004; 24:564-7. 33. Mustafa R, Afreen U, Hashmi HA. Contraceptive Knowledge, Attitude and Practice among Rural Women. Journal of the college of Physicians and Surgeons Pakistan.2008;18(9):542-545.

34. EL-Qaderi SS, AL-Omari N. Knowledge, attitudes, and practices of family planning among currently married women in Jordan Badia. Int Q Community Health Educ. 2000-2001; 20:171-91. 


\section{Author Information}

Neelu Saluja

Assistant Professor, Deptt. Of Community Medicine, Maharaja Agrasen Medical College

\section{Seema Sharma}

Assistant Professor, Deptt. Of Community Medicine, Maharaja Agrasen Medical College

\section{Seema Choudhary}

Associate Professor, Deptt. Of Community Medicine, Maharaja Agrasen Medical College

D.R. Gaur

Professor \& Head, Deptt. Of Community Medicine, Maharaja Agrasen Medical College

\section{S.M. Pandey}

Assistant Professor, Deptt. Of Community Medicine, Maharaja Agrasen Medical College 